$\begin{array}{llll}\text { The Journal of Nepalese Business Studies } & \text { Vol. I } & \text { No. } 1 & \text { Dec. } 2004\end{array}$

\title{
Writing Fieldwork Assignment Reports
}

Prof. Dr. Prem R. Pant*

\begin{abstract}
This paper has been prepared with an objective to provide the guidelines to the BBS students to write the fieldwork report and teachers to guide their students in writing the fieldwork report. So, this paper has included formats of fieldwork report (both in English and Nepali) as prescribed by Office of the Dean, Faculty of Management, Tribhuvan University and procedures to be followed in preparing the report.
\end{abstract}

FIELDWORK STUDY PROJECTS BEGIN with an idea and end with a report. Therefore, writing a report is the final phase of the fieldwork assignment. In other words, the output or the final product of the fieldwork study project is the report itself. This final product in the form of a report is also important for student because it is evaluated and marks are awarded. All important aspects of the report-the procedures, methods and findings-are scrutinized by the examining committee. The purpose of this article is to provide the students with some knowledge of the rules and principles involved in writing a fieldwork assignment. The technique of writing of such assignments discussed in this article should help the students in writing better fieldwork report.

\section{What is a Report?}

A report is simply a statement or description of things that have already occurred. It is a concise, clear communication of the important findings of the fieldwork. A report thus conveys information to the examiner about the entire activities you have undertaken during the fieldwork period. It is the only truly effective way in which you can communicate with your examiners about the interesting findings of your work and the new knowledge you have generated. Thus, even if you have well executed all the steps and procedures in the fieldwork, they are of little use if the findings of your fieldwork cannot be effectively communicated.

\section{The Report Process}

There are five steps in the report process. First, data and information are collected from different sources-literature survey, field survey, data banks/reports and observations, and then collected data are processed. After processing, data are presented in different forms-charts, table, graphs, diagram and pictures. BBS students are expected to use the simple statistical tools like average, percentage analysis, range, index number, correlation, and simple regression, to analyze the collected data. Now, after getting the results of the statistical tools, students should start to write the report.

\section{Types of Reports}

BBS student, depending on the nature of the investigation, can prepare either informational report or analytical report. The information reports are mere description of facts or opinions gathered by the students during their field study. The presentation of facts in an organized way may be of real value in properly understanding the situation. The reports indicate the nature of the problems facing the organization under study and also indicate the reforms required to overcome the problems. Analytical reports go one step further than

$\bar{*}$ Dr. Panta is Professor, Central Department, Faculty of Management, T.U. 


\section{Writing Fieldwork Assignment Reports}

informational reports. These reports, in addition to presenting facts and statistics, interpret this information in relation to the problem under consideration. Focused on a single or limited area of the problem, these reports follow the process of scientific investigation and reporting. These reports also recommend the actions to be taken for improvement in the situation.

\section{Procedures for Writing}

There are no set rules for writing a report. Procedures that work well for one person may not work so well for another. However, certain suggestions are given in this paper for you to consider.

\subsection{Prepare Outline}

Depending upon the data you have collected, you can draw an outline of reporting prior to actually starting the write up. This will help you in arranging your ideas in a better way. This will also enable you to see broadly which information you want to communicate and how the various points are related to one another. Thus, for effective report writing, it is essential to plan its contents well.

\subsection{Plan Your Time}

The date of report submission is decided by the campus. Therefore, you may not have enough time to work at ease. As you have to meet the time schedule, it is always better for you to plan your time accordingly. Delays in submission of the fieldwork report may cause problems for you as well as the campus. Time planning may save you from these inconveniences and last minute rush. It is also better to keep margin of time. If some unforeseen problem causes a delay, you can still submit the report on schedule. By getting started early, you can possibly avoid the submission of a substandard report.

\subsection{Arrange Data}

You may have collected the data from different sources. The raw data need to be processed and tabulated first. After some editing work is done, the data would be somewhat revealing. You then have to arrange the data in some sequential order for meaningful presentation. The better you organize, and arrange the data, the better the data will be revealing.

\subsection{Start Writing}

In writing, the beginning is often difficult. You may begin with the introduction and proceed through to the conclusion. But it is always better to start writing the sections which appear to be especially easy. This would increase your enthusiasm for the task and enhance your level of confidence.

\subsection{Prepare the First Draft}

Never expect to produce the excellent report in the first attempt. This may not even be possible for experienced writers. Therefore, prepare the draft first. Then, rewrite where necessary.

\subsection{Put the Report aside for a Day or Two}

After preparing the first draft, keep the report aside for a day or two can be very beneficial. Then you review the report afresh, almost as objectively as another person. If you find weaknesses, you can remove or correct them. 


\section{The Journal of Nepalese Business Studies}

\subsection{Review and Rewrite}

In any report, there is always some scope for improvement. You must review your work in terms of the format and style of reporting. Ensure that you have followed the format and style prescribed by the Faculty of Management, Tribhuvan University. You should also review your work to identify any errors in grammar, spelling, punctuation, sentence structure etc. Trying to write to perfection in one step would be a mistake for the beginners. Revising may be necessary for better presentation of the report. There is nothing wrong in revising and writing the report. Revision is not merely proof-reading. Proof-reading involves correcting errors. Revision involves pruning out deadwoods, finding more precise words, smoothing the flow of the writing, rearranging words, sentences, and even paragraphs. Revising report involves assuming the role of a reader. Not what you meant to say but what you actually said is important.

\section{Elements of a Fieldwork Report}

A fieldwork report falls into three general divisions: (i) preliminary section, (ii) the main text of the report, and (iii) the supplementary material.

\subsection{Preliminary Section}

Prior to the main body of the report, some pages of preliminary materials-title page, recommendation sheet, table of contents and acknowledgements-are presented.

\subsubsection{Title Page}

The title page is a cover page of the fieldwork assignment report that should include the following information:

(a) Title of the report

(b) Full name, roll number and T.U registration number of the student

(c) Name of the campus

(d) The place and date of the report

All the items of the title page should be centered between the margins of the page. The title should be typed in capital letters. If the title extends beyond one line, it should be $11 / 2$ " spaced and placed in an inverted pyramid style (see Appendix 1.1 and 2.1).

\subsubsection{Recommendation Sheet}

The faculty of Management, Tribhuvan University may also require a recommendation or a certificate of the supervisor and the Department Chairman of the campus. They should certify that the student has undertaken the fieldwork as approved by the Department. The fieldwork report will not be examined by the external examiners unless the supervisor and the Chairperson of the Department certify it. For a model of the recommendation sheet, see Appendix 1.2 and 2.2 .

\subsubsection{Acknowledgements}

The student should write a preface. It should contain a brief statement of the purpose, scope and the organization of the report. In addition to this, thanks may be expressed to those who gave him substantial help, guidance, or assistance in completing the fieldwork project.

\subsubsection{Table of Contents}

This occupies a separate page. It gives the readers a bird's eye view of the report and enables them to locate quickly each section of it. In addition to providing an easy means of 
Writing Fieldwork Assignment Reports

referring to particular sections, it serves as an outline of the subject matters. The chapter headings should be typed in capital letters. The first letter of each word except to the preposition and article in sub-divisions should be in capital. These headings appear in the exact words or order that they are in the report, each followed by the correct page citation. An example of a table of contents is given in Appendix 1.3 and 2.3.

\subsubsection{List of Tables and Figures}

In a fieldwork report having many tables and figures, separate lists of tables and figures are prepared and placed just after the table of contents. These lists of tables and figures occupy separate pages. These lists are prepared in the same form as the table of contents. Examples of the List of the Tables and List of Figures are given in Appendix 1.4 and 1.5 for reports written in English and 2.4 and 2.4 for reports in Nepali.

\subsection{Text of the Report}

The heart of the report is, of course, the main text. Within the text, the writer presents the entire scope of the fieldwork assignment. The text, therefore, includes the main body from introduction to conclusion. The body of the report conventionally consists of three divisions-introduction, presentation and analysis, and summary and conclusions.

\subsubsection{Introduction}

All reports require some introduction. The wider the scope of the report, the more extensive the introduction required.

The introduction orients the reader. It gives him a clear understanding of the background, scope, and purpose of the study. The other information to be included in the introduction chapter of a fieldwork are literature survey, the fieldwork procedures, and the data collection methods used. In short, the introduction tells the reader what the report is about, what the writer did and how he/she went about it.

\subsubsection{Presentation and Analysis of Data}

The discussion and analysis section is the heart of the report. This is the section in which data are presented and analyzed. The discussion of findings will normally be the longer section of the report. The writer must analyze the data by use of appropriate techniques which may include:

(i) The data gathered must be examined in relation to objectives

(ii) The data must be processed and grouped into several items or headings for their analysis

(iii) The processed data should then be presented in the form of tables, charts, diagrams, figures, descriptions, historical narration, etc. to explain the relationships of the data analyzed.

(iv) The use of analytical and statistical techniques should be made for better interpretation of data to draw inferences

(v) The results should be explained in sufficient detail to enable the reader to have an adequate understanding of the work.

\subsubsection{Summary and Conclusions}

The fieldwork report should contain both summary and conclusions. These are not the same thing. A summary is a brief narration of the entire report including the major findings. This summary should give the reader an overall picture of the study. The report-writer should then draw out the significant conclusions and implications of the findings. A conclusion is 


\section{The Journal of Nepalese Business Studies}

thus a deduction based on the findings. Sometimes, the report-writer also proposes some recommendations which are in the form of suggested courses of action.

\subsection{Supplementary Section}

\subsubsection{Bibliography}

The bibliography which is always required in a thesis or report follows the main body of the report. It tells the reader the sources of the researcher's information and gives a clear and complete description of these sources that were used in preparing the report. Generally, a bibliography should include all sources that had a direct bearing on the study, i.e. it must include every reference used in the footnotes and others of significance to the study.

\subsubsection{Appendix}

An appendix, if included, follows the bibliography. The appendix is a storehouse for the tabulations, charts, maps and other illustrative materials which are needed to substantiate points made in the text but are not closely enough related to the discussion to warrant their being placed in the text properly. Thus, the appendix is a section containing a variety of items that are concerned with the study. Such materials as questionnaire, survey instruments, checklists etc. are also included as appendix materials. 
Appendix 1.1: Format of Cover Page

\title{
TITLE OF THE FIELDWORK REPORT
}

\author{
By: \\ Student's Full Name \\ Roll No. : \\ T.U Registered No. : \\ A Fieldwork Report
}

Submitted to:

Name of the Campus

Tribhuvan University

In partial fulfillment of the requirements for the degree of Bachelor of Business Studies (B.B.S.)

Name of Place

Month, Year 
Appendix 1.2: Format of Recommendation Page (on official letter head)

Faculty of Management

TRIBHUVAN UNIVERSITY

\title{
RECOMMENDATION
}

This is to certify that the fieldwork assignment report:

\author{
Submitted by \\ Name of the Student \\ Entitled \\ Title of the Fieldwork
}

has been prepared as approved by this Department.

This fieldwork assignment report is forwarded for examination. 
Appendix 1.3: Format of Table of Contents

\section{TABLE OF CONTENTS}

Acknowledgements

Chapter I : INTRODUCTION

1.1 Background of the Fieldwork Project

1.2 Literature Survey

1.3 Purpose of the Fieldwork

1.4 Fieldwork Procedures

1.5 Methods of Data Collection

Chapter II: PRESENTATION OF THE DATA

2.1 Presentation of Data

2.2 Analysis of Data

2.3 Study Result

Chapter III: SUMMARY AND CONCLUSIONS

3.1 Summary

3.2 Conclusions

\section{BIBLIOGRAPHY}

\section{APPENDIXES}


Appendix 1.4: Format of List of Tables

\section{LIST OF TABLES}

Table

1.1 Population of Pokhara Municipality

Page

1.2 Literacy Rate of Pokhara Municipality 
Appendix 1.5: Format of List of Figures

\section{LIST OF FIGURES}

Figure

1.1 Organization Structure of Pokhara Municipality

1.2 Resource Mobilization of Pokhara Municipality 
परिशिष्ट २.१: मुखपृष्ठको नमुना

\title{
स्थलगत अध्ययन प्रतिवेदनको शीर्षक
}

\author{
तयार पार्ने \\ बिद्यार्थीको पूरा नाम र थर \\ रोल नं : \\ त्रिविवि दर्ता नं :
}

बिबिएस उपाधिको प्रयोजनको निम्ति

क्याम्पसको नाम

त्रिभुवन विश्वविद्यालयमा

प्रस्तुत स्थलगत अध्ययन प्रतिवेदन 
परिशिष्ट २.२: सिफारिस पत्रको नमुना (क्याम्पसको लेटरप्याडमा)

\author{
व्यवस्थापन संकाय \\ त्रिभुवन विश्वविद्यालय
}

सिफारिस पत्र

श्री / सुश्री / श्रीमती

द्वारा यस विभागमा प्रस्तुत

(स्थलगत अध्ययन प्रतिवेदनको शीर्षक)

शीर्षक स्थलगत अध्ययन प्रतिवेदन यस विभागले निधारित गरेको ढाँचा अनुरुप भएको प्रमाणित गरिन्छ ।

यो स्थलगत अध्ययन प्रतिवेदन परीक्षणको लागि सिफारिस गरिएको छ।

स्थलगत अध्ययन प्रतिवेदन निर्देशक

(विभागीय प्रमुखको नाम )

विभागीय प्रमुख 
परिशिष्ट २. २: विषयसूचीको नमुना

\section{विषयसूची}

कृतज्ञताज्ञापन

अध्याय एक : भूमिका

१.१ स्थलगत अध्ययनको पृष्ठभूमि

१.२ पूर्वाध्ययनको विवरण

१.३ स्थलगत अध्ययनको उद्देश्य

१.४ स्थलगत अध्ययनको प्रक्रिया

१.५ तथ्याङ संकलन विधि

अध्याय दुई : तथ्याङ्के प्रस्तुतीकरण र विश्लेषण
२.१ तथ्याङ्के प्रस्तुतीकरण
२.२ तथ्याङ्को विश्लेषण
२.२ अध्ययनको परिणाम

अध्याय तीन : उपसंहार र निष्कर्ष
३.१ उपसंहार
३.२ निष्कर्ष

सन्दर्भसूची

परिशिष्ट 
परिशिष्ट २.४: तालिकासूचीको नमुना

\section{तालिकासूची}

तालिका

१.१ पोखरा उप-महानगरपालिकाको जनसंख्या विवरण

१.२ पोखरा उप-महानगरपालिकाको साक्षरता विवरण 
परिशिष्ट २.५: चित्रसूचीको नमुना

\section{चित्रसूची}

चित्र

१.१ पोखरा उप-महानगरपालिकाको सांगठनिक स्वरुप

१.२ पोखरा उप-महानगरपालिकाको स्रोत परिचालन विवरण 